\title{
REVIEW ARTICLE: Law of Desire: Temporary Marriage in Iran
}

\author{
Mandana Hendessi
}

Law of Desire: Temporary Marriage in Iran

Shahla Haeri

London: IB Tauris 1990

$£ 9.95$ pbk, ISBN $1850431701 \quad £ 22.95$ hbk, ISBN 1850431574

Shi'a Islam has a practical and nonsentimental approach to marriage. It defines marriage as merely a 'contract of exchange' which entitles a woman to receive a specified sum of money or valuables in return for granting a man exclusive sexual rights. Jabiri-Arablu, a contemporary scholar, provides an even more specific and precise definition of marriage: 'a contract of ownership, tamlik, of the use of [the] vagina' (Haeri, 1990). That is to say, marriage clearly involves the sale of a woman's vagina to a man. However, given this definition, there are two distinct types of marriage currently practised in Iran: temporary and permanent. The former is the prime focus of Law of Desire.

Having raised some crucial, yet previously neglected, questions with regard to the implications of the concept of marriage as a contract of exchange for women in their personal relations with men, Haeri, in Law of Desire, purports to demystify the logic of marriage in the Iranian society. She argues that despite the clear assumption of ownership and purchase contained within the definition of marriage, the shi'a ulama (clerics) have consistently avoided discussing the implications of this analogy for marital relations. This has given rise to ambiguities and confusion which has had serious implications, for women in particular.

In the case of temporary marriage, the confusion is even more serious since the linguistic distinction has been blurred. Unlike the ordinary (permanent) marriage, nikah, where the prime objective of the 'contract' is defined to be procreation, temporary marriage, mut'a, is contracted for sexual pleasure, as the literal meaning of the word 
suggests in Arabic. In this case, a woman enters a time-limited contract for sexual favours, hence there would be no permanent exchange of 'ownership'.

The Shi'a ulama, however, have clouded the term by referring to both as marriage: permanent and temporary respectively. This misplacement of emphasis on the marital aspect, has created the impression that mut'a is merely a form of marriage but with a 'built-in time limit'. Furthermore the colloquial application of mut'a, sigheh (a form of contract), has remained more loyal to the literal meaning, creating further confusion and uncertainty for those men and women who have made use of this form of marriage contract, says Haeri. In the case of women, this confusion, as illustrated in the case studies, has accentuated their vulnerability in the society. This is manifested in the women's life stories which reveal their isolation within a system that, in theory, encourages mut'a unions as divine and sacred despite the prevailing social and cultural ambivalence toward it.

Through detailed examination of the theoretical and practical application of mut'a with the support of fascinating case studies of both men and women who have contracted it, Haeri demonstrates the complexity of this social issue. She states that contrary to the common belief among many Iranians, $m u t^{\prime} a$ is not an Islamic innovation. It is a form of sexual union which was customary in some pre-Islamic Arabian tribes as well as in Iran before the Arab conquest (seventh century AD). In its ancient Arabian form, mut'a was a temporary alliance between a woman and a man, often a stranger who was seeking protection among her tribe. She cites Robertson Smith who claims that on the formation of such an alliance, a man would be given a spear and a tent as means of incoporating him into the group 'politically and affinally'. Since the woman lived among her own tribe, she maintained close links with kin and continued to enjoy their protection. Children born during such temporary unions traced their decent through the mother's lineage and would hence remain with her tribe, whether or not the father took up permanent settlement among his wife's tribe.

In its ancient Iranian (Zoroastrian) context, the husband or the father had the right to hand over his wife or daughter to another man belonging to his community. This involved a formal procedure initiated by a formal request from the latter. However, the wife remained the permanent spouse of her first husband throughout and any children born during this temporary arrangement belonged to the woman's permanent husband, or her father. The striking similarity between the current and ancient practice of mut'a rests in the underlying assumption which regards men as lawful guardians of women - the unchanging face of patriarchal social relations.

The practice of $m u t^{\prime} a$, says Haeri, continued in its pre-Islamic form in Arabia until it was outlawed by the second Islamic Caliph, Umar. However, it was later reconstructed by Shi'a religious leaders, who opposed Umar, to take the, more or less, present form which significantly favours the position of men. 
Furthermore, given the prevailing custom of temporary union in Zoroastrian religion, the Iranian incorporation of mut'a in the postIslamic period was to take the patriarchal form - compatible with the local tradition. It was generally the case that certain interpretations of early Islamic teachings, which were compatible with Iranian social and cultural modes of thought and behaviour, emerged during this period and were subsequently incorporated in the Islamic law of Iran.

The present practice of mut'a in Iran, say Haeri, regards the woman as both the lessor as well as the object of the lease - in contrast with the ancient form where the woman was only the object. She quotes a mullah (Muslim preacher) explaining the difference between the two types of marriage. Permanent marriage, says he, is like 'buying a house'. It involves greater financial commitment both in terms of brideprice (if the woman is virgin she is entitled to a higher rate) and the arrangement for the wife's daily upkeep. It also carries a greater social value and prestige. A mut'a contract, by contrast, is like 'renting a car'. It entails lower financial commitment as well as a lesser degree of personal, social and moral responsibility for the spouse.

The contemporary Shi'a Islam places men in control of mut'a unions by granting them special privileges: $m u t^{\prime} a$ can only be contracted with an unmarried woman while the man's marital status at the time of the contract is immaterial and there is no limit to the number of mut'a marriages a man contracts, whereas a woman can only have one at a time. She must also keep a period of abstinence, idda, after the expiry of a mut'a union. The waiting period for this type of union, explains Haeri, is two menstrual cycles for women who menstruate regularly and forty-five days for those who are at an age where they normally ought to menstruate but for some physiological reason are unable to. Thus it appears that everything regarding the responsibilities of the women engaged in mut'a unions is thoroughly defined to facilitate religious and social control of women. Evidently the Shi'a ulama justify this rule on the basis of the need to determine pregnancy and hence establish paternity.

Unlike the permanent marriage, where an elaborate ceremony is involved, mut'a contract requires only a simple one which may be performed either by the man or the woman themselves, or by a mullah. Due to its strong resemblance to prostitution, many Iranians have defined mut'a as concubinage or legalized prostitution. This, argues Haeri, is an over-simplification of the issue.

The main difference between mut' $a$ and prostitution lies in the fact that children born in mut'a unions are their father's legal heirs and have equal status, in theory, with the children of permanent marriage before the law. Another is the religious distinction: prostitution, in religious terms, represents disorder, disobedience to the established rules. It is fornication (zina) which is explicitly condemned in Islam and is considered a crime punishable by death by stoning under the Iranian Law of Retribution (enacted in 1981). Mut'a, on the other hand, symbolizes social control and harmony with the social order. 
The main point is that, although neither the contemporary Islamic leaders in Iran, nor, on the whole, the Islamic religion, deny the existence of sexuality in women and men, both regard it as destructive to the social order if it is not controlled and regulated.

The practice of mut'a has been inconsistent throughout Iranian history. In the nineteenth century, it was commonplace among the upper and propertied middle classes. The then ruling dynasty, for example, was notorious in the abuse of mut'a. Haeri mentions Fath Ali Shah, one of the Qajar kings, who would even kidnap women for this purpose.

During the reigns of the Pahlavis (1928-78), particularly in the latter decades, mut'a was looked upon as backward and immoral. In the seventies, the law empowered the newly established Family Court to grant a second marriage only if the permission of the existing wife had been obtained. Since the establishment of the Islamic Republic (1979), however, mut'a has undergone a conceptual transformation, with an almost completely new meaning and different participants. Besides a considerable increase in the number of mut'a unions due to the regime's promotion of it, the effected groups of people represent a cross-section of the population. Whereas before the revolution, mut'a was limited to the more religious and traditional sectors, it is now contracted by other classes and social groups.

As demonstrated by Haeri, the regime has made a concerted effort to introduce mut'a to the wider society. It is the subject of a detailed article in Religious Education textbooks for secondary-school students. The text outlines a number of reasons for the necessity of mut'a: youth have urgent sexual needs; sexuality is one of the most important motivating desires in human beings; permanent marriage is costly and includes all kinds of obligation which could interfere with their education, etc.

Social stereotypes hold that women contract mut'a for financial reasons while men do so for sexual pleasure. Haeri shatters this myth by revealing in the case studies that women's primary motive in mut'a unions is not money but an attempt to achieve a more secure social status and for sexual relations. One of her female informants, Mahvash Khanum, for instance, openly admits that she contracts mut'a for sexual satisfaction while another, Furugh Khanum, has achieved the desired secure status for herself and her daughter through contracting mut'a with a respectable merchant.

Law of Desire is a comprehensive study of an ancient, yet enigmatic, institution. It has involved crossing many difficult as well as obscure boundaries. As the author admits, the most difficult methodological issue was the identification of people who contract mut'a since, due to the prevailing social ambivalence toward it, many Iranians kept their temporary unions secret. This was the case even after the revolution and despite the Islamic regime's positive approach to mut'a.

The granddaughter of a well-respected and famous ayatollah, Shahla Haeri was able to enter the secluded world of $m u t^{\prime} a$ unions in the 
holy cities of Qom and Mashad and unfold the truth about this form of marriage through the eyes of the real people who entrusted her with their 'secrets'.

Law of Desire contains some very interesting, often heartsearching, life stories of women. Although it is an academic and descriptive study of a specialist topic, the language, the style of analysis and narrative render it readable, stimulating and appealing to a nonspecialist readership. It is the first of its kind to deal with a taboo issue which, despite its social and political importance has been neglected and overlooked by a wide range of political opinion in Iran.

Due to its strong resemblance to prostitution, the institution of mut'a has been regarded by the secularists, including the Iranian socialist feminists, as religiously sanctified prostitution which will eventually be uprooted in the aftermath of some future socialist revolution. This outlook has grossly disregarded the plight of mut'a women who are inevitably caught in the web of moral tensions between the two institutions. It merely reinforces the prevailing social values which regard mut'a women as undesirable and unworthy. Furthermore, it exposes the left's condescending outlook towards prostitution.

The social ambivalence towards mut'a reflects the general ambivalence towards women and female sexuality. The popular image of women suffers a binary perception: women are portrayed in PersoIslamic literature and folklore as controller/controlled, seducer/ seduced, cunning/gullible, and pious/adulterous. Haeri cites the Tales Of A Thousand and One Nights where these binary images strongly feature. The whole story is based on one such binary opposition where the mediation of a woman, Shahrezad, brings order to a society disordered by the cunning of an adulterous queen. The Qor'an (Muslim holy book), says Haeri, itself, reflects this ambivalence: women are sometimes depicted as objects to be treated harshly or kindly and at other times as people equal to men. Mohammad, the prophet of Islam, also talked of women in paradoxical terms: women, in his view, were both 'the trappings of Satan' and one of the most precious objects on earth - the other being perfume!

With regard to female sexuality, the Shi'a ideology maintains its own peculiar ambivalence. It is seen as the source of energy desperately sought by men, life-giving as well as life-threatening, frightful as well as charming; necessary and superfluous at the same time. This, argues Haeri, may partly explain the obsession with veiling which is meant to conceal, even disfigure, a woman, this fascinating creature 'before whom men are presumably reduced to their bare instincts'.

Law of Desire challenges, though subtly, the view held by the feminist supporters of the Islamic regime who claim that Islamic marriage, whether permanent or temporary, ensures that women are financially rewarded for fulfilling their part of the marital bargain and provides them with status, emotional satisfaction and a central role in society. Furthermore, they allege that the institution of mut'a allows women the freedom of entering a mutually desirable contract of 
marriage on an equal footing with men. This echoes the views of the leading male theologians, like Ayatollah Najafi Mar'shi, who have stated that women suffer no compulsion; they are 'free' to agree a contract of temporary marriage.

This outlook dismisses the fact that women and men negotiate the terms of a mut'a contract from a position of profound inequality in the first place. Mut'a is an institution which legally, socially and economically places women in an inferior position by granting men special privileges. Moreover, given that it operates within the context of a society where men enjoy a conspicuously dominant status, it cannot but offer women a limited scope to negotiate let alone do it on an equal basis! The case studies cited in Law of Desire demonstrate the inherent contradiction between male and female perceptions and experiences of mut'a marriage. Most of the female informants expressed their dismay of the institution of temporary marriage of which they saw themselves a victim. They hoped for a meaningful and perhaps lasting relationship with their mut'a partners whom, by contrast, exhibited a perception of them as 'provisional objects' satisfying their repressed needs and enabling them to escape the daily routine and rigidly structured domestic life. Whereas mut'a women often viewed their temporary partners as their main sustenance, the men perceived them as supplementary to their lives - a bit on the side (does that sound familiar?). While the women articulated a sense of self-doubt, a gullible self, men appeared to project strong self-concepts, a desirable self, concludes Haeri.

Muslim feminists aside, there is a growing tendency led by some secular Third World feminists who, in an attempt to come to grips with the Islamic fundamentalist successes in the Muslim world, have conceded that many women are adopting the veil and the traditionalist approaches to gender relations as 'a revolutionary act'. In an article published by the Independent (20 November 1990), Haleh Afshar argues that many women in Iran, Algeria, Egypt, Lebanon and elsewhere in the Muslim world, have sought the real dignity and power in the veil and the traditional tenets of Islam in a gesture of rejection of the West. But the key question, which has been given little consideration by this tendency, is whether there has been a real choice for women in these countries where the most basic democratic right - the right to freely assert one's individuality, is heavily repressed.

Afshar draws an analogy between the Muslim feminists' claims of liberation through fundamentalist Islam and the campaigns led by some feminists in the West. The veil, she says, is regarded by Muslim feminists as the creator of a private female space which allegedly purports to alleviate the objectification of women. This argues Afshar, compares well with the Western feminists' struggles against pornography and for the creation of space for women in a male world. In other words, the seclusion of women, the centuries-old tradition upheld by the Muslim feminists as a factor militating against regarding women as mere sex objects, is consistent with the 'women only' meetings and 
events organized in the West by feminists who wish to create a space for women's free expression. Are these two phenomena comparable? Are we not falling into the trap of over-simplification of the issues by examining both of these concepts outside their social context? Are we doing each one the justice it deserves by trying to find points at which they converge rather than analysing them within the historical context to which they belong?

Feminism in the West constitutes a radical dynamic born from very specific social movements which took form within the context of a liberal socio-political structure: the struggle for universal franchise, the campaigns against sex discrimination in employment and for equal opportunity, the demand for free abortion and child care being some of its components. Historically, this liberal tradition has been unable in countries such as Iran and Algeria to give rise to a feminist movement capable of independent assertion; one which is strong enough to effectively challenge the traditional and oppressive gender relations.

Afshar is right to say that there have been Western-style feminist struggles in these countries dating back to the turn of the century. But, due to the prevailing uneven socio-economic development resulting from years of colonialism and imperialism, these movements, however genuine, have only managed to embrace an intellectual minority. This minority remains unable to challenge the ideology and outlook of the state. It has now been increasingly acknowledged that in a desperate attempt to survive, feminism in the post colonialist era has had to latch on to the state or to male-dominated political parties in opposition, none of which has sufficiently, if at all, addressed gender inequality. Iran provides a clear example of this pattern of development where the embryonic feminist movement in the early twentieth century was later incorporated by the modernist government of Reza Shah Pahlavi in the 1930s. This situation continued through the reign of his son, the late Shah, until the 1979 revolution, during which the emerging independent, yet incoherent, feminist movement was ruthlessly marginalized by the leaders of the revolution. The only surviving and cohesive component of the movement, Muslim fundamentalist feminism, was later incorporated by the Islamic government in an attempt to appeal to the majority of women. It is only this surviving component which is allowed expression under the watchful eyes of the Islamic leadership. So, is there a choice?

It is precisely the illusion of women having a choice in today's Iran that Law of Desire obliterates through an exhaustive examination of the tradition of mut'a marriages. It powerfully illustrates the gender inequality inherent in Perso-Islamic social and legal relations as reflected in this old, yet changing, institution. Law of Desire embodies a challenge to all those who endeavour to conceal repressive Islamic precepts in a radical garb or justify, consciously or otherwise, the sexual politics of Islamic fundamentalism. 


\section{Notes}

Mandana Hendessi is a researcher and writer, specializing in women and development, and global immigration issues. She is the author of Migrants: the Invisible Homeless (London Voluntary Service Council, 1987); and Armed Angels: Women in Iran (Change, 1990). 